\section{Social Work} \& Education

CSW\&E, 2021
Клос, Л., Джавадян, О.-М. (2021). Соціальна

реклама як приклад сучасної практики соціальної роботи в україні. Vol. 8, No. 2 . Ternopil-Aberdeen, 2021. pp. 190-203. DOI:

10.25128/2520-6230.21.2.5.

УДК $(316.3+316.35)$ : (364-

$4+364-7+364.4+364.6)$

DOI:

$10.25128 / 2520$

6230.21.2.5.

\title{
СОЦІАЛЬНА РЕКЛАМА ЯК ПРИКЛАД СУЧАСНОЇ ПРАКТИКИ СОЦІАЛЬНОЇ РОБОТИ В УКРАЇНІ
}

Лілія Клос, доктор педагогічних наук, доцент, завідувач кафедри соціології та соціальної роботи,

Національний університет «Львівська політехніка», Львів, Україна; liliia.y.klos@lpnu.ua, ORCID ID: https://orcid.org/00000001-9972-7450

Олександра-Марія Джавадян, магістр соціальної роботи, студентка 2 року програми підготовки докторів філософії за спеціальністю «Соціальна робота»,

Національний університет «Львівська політехніка», Львів, Україна; alexandradzhavadian@gmail.com ORCID ID: https://orcid.org/00000002-7656-7578
Анотація. У статті розглянуто окремі аспекти соціальної реклами в Україні, описано основні характеристики соціальної реклами, як однієї із сучасних практик в Україні, а також перспектив розвитку та застосування соціальної реклами в професійній соціальній роботі. Визначено види соціальної реклами, функції які вона виконує в системі соціальної роботи та завдання які може здійснювати в перспективі. Проведено аналіз теоретичних праць вітчизняних та закордонних фахівців, а також звітів про соціальну рекламу, звітів Національної ради, які дозволяють зробити підсумок про те, що соціальний працівник завдяки соціальній рекламі, може здійснювати профілактику, сприяти соціалізації, адаптації, інформуванню та покращувати соціальний клімат в країні, попереджувати суспільство про певні проблеми та мінімізувати їх поширення.

Ключові слова: соціальна реклама; профілактика; практика соціальної роботи, соціальна послуга профілактики. 


\section{Вступ}

Соціальна робота в Україні уже встигла окреслити свої межі як галузь наукових знань, теорія і практична діяльність. Ця сфера професійної діяльності в сучасних умовах проходить етап зростання зацікавленості з боку населення i, що особливо важливо, зі сторони тієї частини громадян, які мають важелі законотворення. У січні 2020 р. вступив у дію новий Закон України «Про соціальні послуги», в якому зафіксовано перехід від наголосу на «допомозі в подоланні складних життєвих обставин»до акценту на «профілактиці, подоланні та мінімізації негативних наслідків СЖО»(Закон про соціальні послуги, 2020). Профілактична спрямованість соціальної роботи вимагає застосування фахівцями відповідних дієвих інструментів впливу на споживачів соціальних послуг. Серед інших, важливим засобом профілактики складних життєвих обставин і загалом соціальних проблем, у світі вважається соціальна реклама.

Сучасна соціальна реклама відображає багато важливих питань та проблем суспільства, але не домінує як комунікаційний фактор впливу, тому що залежить від ініціаторів розповсюдження (благодійні, некомерційні організації), які забезпечують розроблення, виробництво та розповсюдження реклами. Більшість 3 них розглядають соціальну рекламу як окрему кампанію або захід. Але, все ж таки, соціальна реклама піднімає доволі багато превентивних та соціальних тем та елементів (норми, знання, моделі поведінки, цінності), що дозволяє вважати іiі вагомим чинником впливу на суспільство (Яненко, 2017).

Проблеми сучасної соціальної реклами вивчали зарубіжні та українські дослідники. Питання профілактичної діяльності фахівців соціальної сфери розглядалося в зарубіжних роботах - К. Гланц, К. Вішванат, Б. Рімер, які пишуть про сучасні та нові теорії комунікацій зі здоров'ям, електронне здоров'я, спільноти та стрес, про те яку роль відіграє в цьому соціальний маркетинг та соціальна робота (Glanz, \& Rimer, Viswanath, 2008), Дж. Боді, Л. Домінеллі, які розкривуають поняття етики, соціальної справедливості та правильно сформованих цінностей (Boddy, J. \& Dominelli, L., 2016).

Роль соціальної реклами у формуванні думки та цінності людей вивчали такі вітчизняні науковці як О. Бугайова, Н. Лисиця, Т. Лобойко, Л. Березовець, О. Грабчак та ін. Вони у своїх працях говорять про вплив на формування цінностей, поведінки, формуванню особистості засобами соціальної реклами, хоча їхні думки на рахунок рекламного впливу, а також його ефективності дещо відрізняються. Кандидат педагогічних наук Тимошенко А. Л., яка досліджує соціальну рекламу з точки зору педагогіки, вважає, що саме соціальна реклама може бути людним 3 найефективніших соціально-педагогічних засобів роботи 3 суспільством та здійснює позитивний соціалізуючий вплив на нього, оскільки впливає на процес розвитку особистості. Проте питання застосування соціальної 
реклами в соціальній роботі як однієї із сучасних практик професійної діяльності соціальних працівників не вивчалося.

Метою статті є визначення характеристик соціальної реклами як однієї із сучасних практик в Україні та перспектив іiі розвитку i застосування в професійній соціальній роботі.

Методологічна основа дослідження: використано методи пошуку, відбору, систематизації наукових та науково-методичних публікацій, поданих у відкритому доступі на платформах наукових журналів і наукових установ та ЗВО за означеною тематикою; їх аналіз за критерієм характеристики основних термінів дослідження «практика соціальної роботи», «профілактична діяльність соціального працівника», «соціальна реклама», а також порівняння, синтез, узагальнення отриманої інформації, метод прогнозування.

\section{Основна частина}

У філософському трактуванні практика (від грецьк. практіка - справа, діяльність, учинок) - поняття, що характеризує особливий різновияв активності людського світовідношення, філософське витлумачення котрого тяжіє або до універсалізму (коли П. поєднує учинково-моральнісні, пізнавальні та етичні характеристики), або до локалізації чуттєво-матеріального (що спричиняє занижену оцінку П.) (Табачковський, 2002, с. 519-520). Дещо спрощене трактування цього поняття, представлене у тлуманому словнику української мови, визначає практику як цілеспрямовану діяльність людей, що має своїм змістом перетворення природи, матеріального світу, вдосконалення суспільних відносин, створення необхідних умов існування суспільства, втілення в життя ідей, планів, намірів) (Практика, 1976, с.513). У навчальному енциклопедичному словнику-довіднику «Все про соціальну роботу», практика окреслена як частина професійної освіти студентів, у якій вони застосовують знання, вміння та навички, отримані попередньо при виконанні авдиторних завдань, у безпосередній практичній роботі з клієнтами (Піча, Гайдук, \& Клос (Укл.), 2014, c. 317-318).

Науковець Т. Семигіна визначає практику в соціальній роботі як «втручання на етапах взаємодії людей з їхнім оточенням»(Семигіна, 2020, с. 82). При цьому авторка пояснює, що оточення - це різноманітні соціальні системи, до яких залучені люди, у тому числі й природне, географічне середовище, що суттєво впливає на людське життя. Дослідниця наголошує на змісті практики соціальної роботи як процесі залучення людей і структур задля вирішення (соціальних) проблем і покращення добробуту.

Практику соціальної роботи характеризує чималий спектр видів діяльності, що охоплюють різноманітні форми втручання (терапії, консультування), групову 
роботу і роботу в громаді, розроблення й аналіз соціальної політики, втручання 3 метою адвокування i змін на рівні політики. Тобто поєднання мікро, мезо i макрорівнів втручання формує цілісну практику соціальної роботи, водночас іiі пріоритети різнитимуться 3 огляду на особливості та специфіку країни, залежатимуть від конкретних історичних, культурних, політичних, соціальноекономічних умов (Семигіна, 2020, с. 83).

В умовах українського сьогодення, практика соціальної роботи, з урахуванням сучасної законодавчої бази, представлена соціальними послугами, що спрямовані на профілактику складних життєвих обставин, подолання або мінімізацію їх негативних наслідків, особам/сім'ям, які перебувають у складних життєвих обставинах (СЖО) (ЗУ «Про соціальні послуги», 2020). Тобто акцент у сучасній практиці соціальної роботи в Україні передбачений саме на профілактичній діяльності. Виходячи 3 цього, доречно звернутися до тих видів практики соціальних працівників, які найбільшою мірою сприяють запобіганню СЖО, $є$ превентивними. Міністерство соціальної політики України затвердило Державний стандарт соціальної послуги профілактики (2015р.). Заходи цієї послуги можуть бути реалізовані через певні форми, першочерговою 3 яких $є$ соціальна реклама, що включає розроблення, тиражування, розповсюдження інформаційних матеріалів, соціальної реклами. Ця форма соціальної послуги профілактики може застосовуватися для надання послуг первинної, вторинної й третинної соціальної профілактики; іiі вибір залежить від потреб отримувача та мети надання послуги (Наказ Мінсоцполітики України № 912, 2015).

Основною задачею соціальної реклами є зміна погляду та ставлення людей до певної проблеми, запобігання виникненню i розповсюдженню проблеми, iі попередження, а в майбутньому - формування нових правильних соціальних цінностей та навичок. Тож можна стверджувати про важливе просвітницьке значення соціальної реклами.

Соціальна реклама виникла на зламі XIX i XX ст., тому іï можна вважати досить молодим напрямом у сфері суспільних комунікацій (Романовська, 2019). У 1904 році почалась історія соціальної реклами. Тоді «Американська громадянська асоціація» створила кампанію на захист Ніагарського водоспаду від шкоди, якої йому завдавали енергетичні компанії. Щодо нашої країни, то лише в редакції Закону України «Про рекламу» від 2003 р. вперше з'явилося поняття «соціальна реклама» в юридичній площині. До цього використовували термін «соціальна рекламна інформація». За межами нашої країни використовують поняття «суспільна» або «некомерційна» реклама.

Некомерційна реклама - це така реклама, що поширюється неприбутковими організаціями задля їх інтересів. Мета неприбуткової реклами - привернення уваги до питань або ситуацій, які пов'язані з людьми, наприклад, з особливими 
потребами, або збір пожертвувань чи агітація. Тобто можна стверджувати, що соціальна реклама має значення, як засіб інформування населення.

Суспільною (соціальна) рекламою, згідно з Законом про рекламу, є будь-який вид інформації, розповсюдженої в будь-якій формі, що спрямовується на досягнення суспільно корисних цілей, популяризацію загальнолюдських цінностей; іiі розповсюдження не має на меті отримання прибутку (Лаврик, 2008).

На думку дослідника Б. Обритька, соціальна реклама представляє некомерційну інформацію державних органів і громадських організацій 3 питань, які стосуються здорового способу життя, охорони природи, профілактики правопорушень, соціального захисту населення тощо (Обритько, 2002). Таке визначення змісту соціальної реклами дозволяе вважати іiі також важливим засобом соціальної профілактики.

Головний редактор журналу «Практична психологія та соціальна робота» О. Губенко проаналізував розвиток соціальної реклами в Україні. За результатами проведеного дослідження автор дійшов висновку, що $52 \%$ українців узагалі не знають, що таке соціальна реклама. Із тих, кому відоме таке поняття, 65\% ставляться до нього позитивно, $20 \%$ не вбачають у такій рекламі великої користі й лише 15\% вважають, що вона потрібна (Український тиждень, 2009). Таким чином, можна припустити, що значення соціальної реклами на початку 2000-их років в Україні було недостатньо оцінено як інформаційного, просвітницького, профілактичного засобу роботи з населенням.

Аналіз сучасний стан розповсюдження соціальної реклами дає змогу зауважити, що поступово вона набирас більших масштабів, а відповідно i більшого значення. У сьогоденні відбувається активний розвиток соціальних мереж та розповсюдження медіавпливу на людей, це сприяє поширенню соціальної реклами в Україні. В таких умовах слід зрозуміти, в якій сфері найбільше і як корегувати іï вектор в ефірі телебачення.

Соціальна реклама має торкатися питань і проблем, що дійсно хвилюють більшість населення. В той же час вона має привертати увагу до проблем меншості. При створенні таких меседжів потрібно звертати увагу, щоб це була не тільки кількість, звучність та оригінальність, але й загальна ідея, яку потрібно «донести до мас» і яка б зацікавила цільову аудиторію. Якщо ж меседжі викликають негативні емоції, відторгнення, нерозуміння, не враховують психологічних та культурних особливостей суспільства, то таку рекламу не можна вважати ефективною.

Проведений аналіз звітів про соціальну рекламу в 2019 р. дає можливість зрозуміти, що основну кількість соціальної реклами на телебаченні становила політична реклама, і була пов'язана з виборами Президента та Верховної Ради. 3 січня по березень 2019 року 19 загальнонаціональних та супутникових телеканалів поширювали соціальну рекламу. Найбільше охоплення аудиторії 
показали такі телеканали як «Україна», «СТБ», «СТV», «Новий канал» і «UA:Перший». Цей рейтинг створено за показником WGRP (Weighted Gross Rating Points), який застосовується для оцінки ефективності рекламних кампаній на телебаченні та розраховується як рейтинг кожного ролика, що множиться на коефіцієнт ціни для цієї довжини ролика. За одиницю зазвичай береться 30 секунд.

354 відеороликів, які відповідають вимогам Закону «Про рекламу», найбільше були на тему виборів Президента України, реформ та діджиталізації, охорони здоров’я, пам'ятних та історичних дат (Звіт Наџіональної ради «Соціальна реклама на телебаченні», 2019).

Огляд i аналіз звіту, який підготувала Національна рада y cniвпращ̧і 3 Індустріальним телевізійним комітетом (ITK) свідчить, щзо замовниками соціальної реклами у I кварталі 2019 р. були різні державні інституціії $i$ представники громадського сектору та бізнесу. Серед основних замовників Кабінет Міністрів України, Міністерство внутрішніх справ України, Благодійний фонд «Розвиток України», Громадська спілка «Орфанні захворювання України».

Глибше вивчення матеріалів звіту дало змогу зауважити, що відсутня соціальна реклама, яка б могла здійснювати превенцію, сприяти соціалізації, виконувати роль соціального працівника і покращувати соціальний клімат в країні, попереджувати суспільство про певні проблеми та не дозволяти їм поширюватися, виконувати інформативну функцію для різних верств населення від імені різних соціальних, громадських та благодійних організацій.

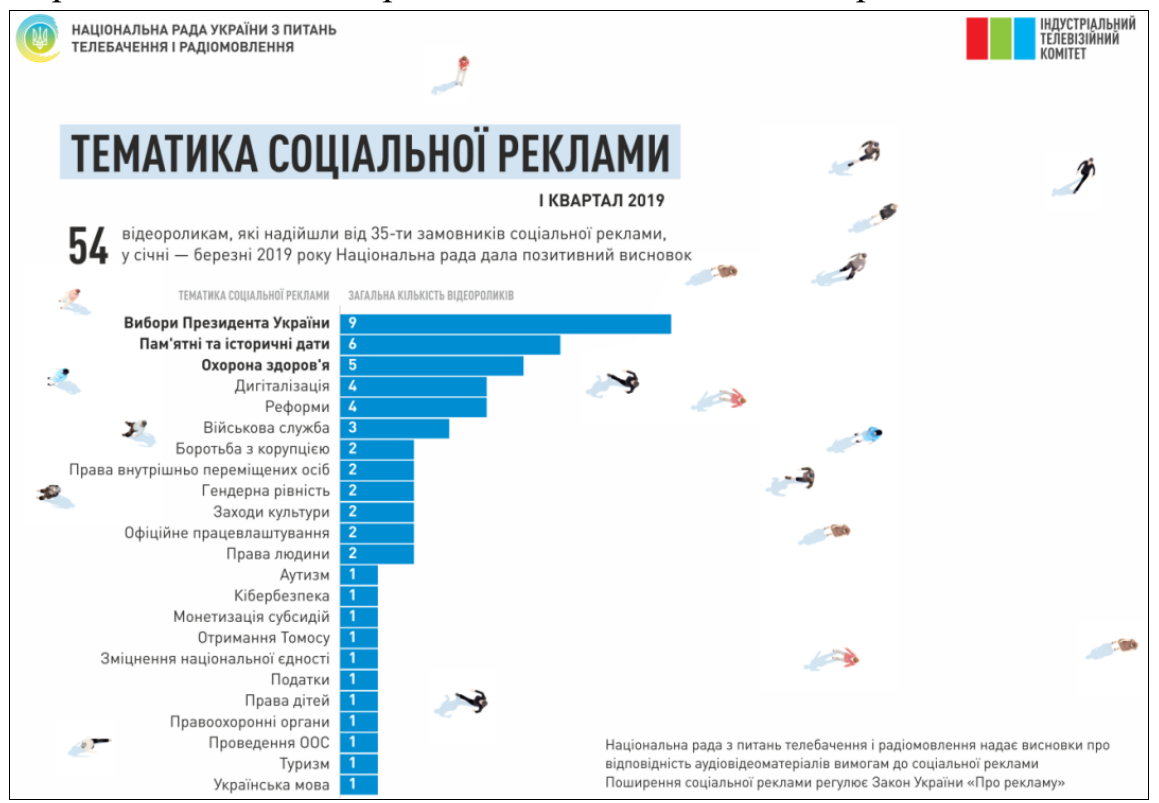

Рис. 1. Тематика сочіальної реклами, I квартал 2019 р. (Звіт Національної ради «Соиіальна реклама на телебаченні», 2019). 
Тож очевидно, що в українських реаліях проблема ефективності соціальної реклами не в пріоритеті, на відміну від низки розвинених (з огляду на стан соціальної сфери) країн. I великою перешкодою в цьому є відсутність поважного замовника соціальної реклами в Україні. Потенційні рекламодавці соціальної реклами - це професійні об'єднання, громадські організації, благодійні фонди, державні структури, бізнес та багато інших. В Україні ж, в умовах обмеженого бюджету, витрачати його без прибутку не поспішають. Громадські організації, які представляють великі міжнародні організації, також не дотримують бюджет через певну непрозорість виділення коштів. Тому головним замовником української соціальної реклами залишається держава. Але у зв'язку із наявністю інших, більш нагальних проблем, як от, економічної кризи, пандемії COVID-19 та війни 3 Росією, бюджетних коштів на розвиток такої реклами виділяється достатньо.

Оскільки засоби масової інформації займають провідне місце у формуванні соціальних уявлень, то відповідної уваги вимагає соціальна реклама, яка виявляє та відображає соціальні проблеми, значимі для суспільства загалом і такі, що потребують нагального вирішення. На наше переконання, соціальна реклама має бути невід’ємною частиною роботи соціального працівника. Відповідно до цілей, завдань та цільової групи має формуватися соціальна рекламна кампанія та реалізовуватися із дотриманням поставленої мети. Кваліфікований фахівець соціальної роботи має вміти розробляти концепцію реклами, консультувати та контролювати проектувальну групу.

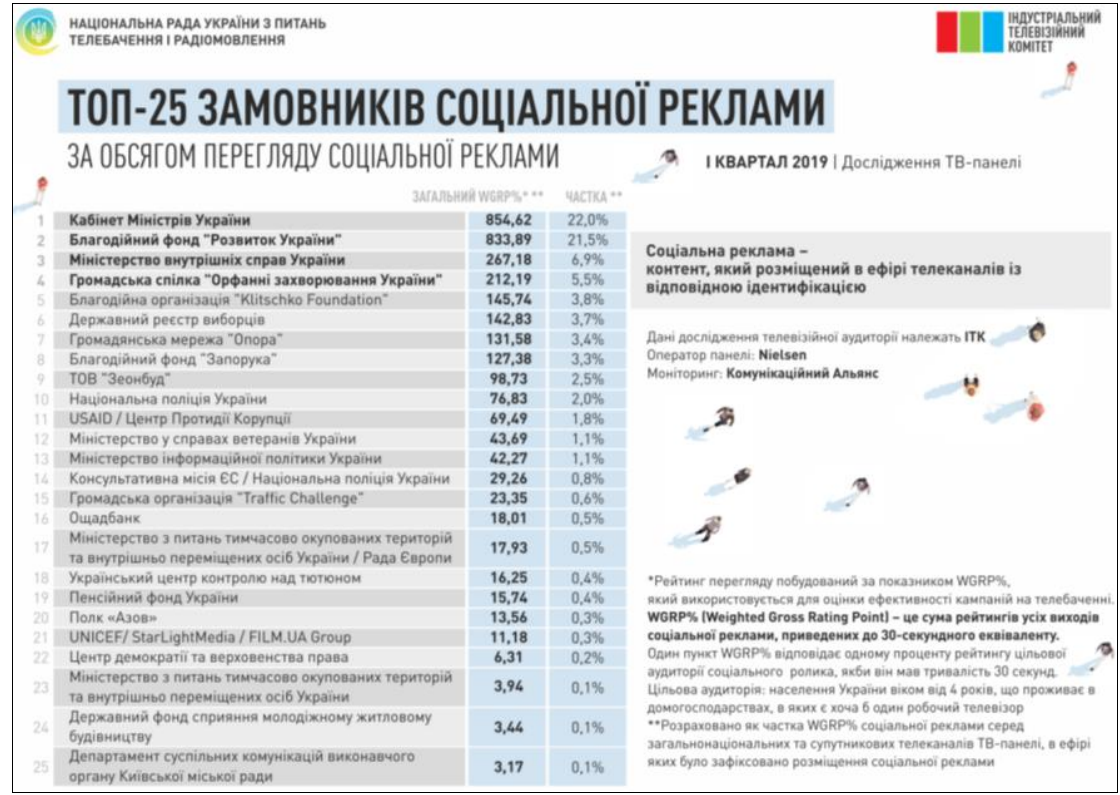

Рис. 2. ТОП-25 замовників сочіальної реклами за обсягом перегляду соиіальної реклами, I квартал 2019 р. (Звіт Національної ради «Соиіальна реклама на телебаченні», 2019). 
Соціальна реклама може і повинна бути одним із засобів досягання успіху в соціальній роботі на шляху до здорового суспільства. Вона має допомагати тим, хто опинився у СЖО. Але краще працювати на випередження, профілактику, щоб допомогти проінформувати людей у групі ризику та не допустити ситуацій, коли вони стануть заручниками важкого становища.

Соціальна реклама виконує важливі функції в системі соціальної роботи:

1) акцентування уваги на існуванні соціальних проблем (багато людей не бачать проблему, доки вона не торкнеться їх, а інколи не помічають, як вже самі потребують допомоги, тому соціальна реклама має привернути увагу до можливих проблемах і алгоритму їх вирішення);

2) залучення та проведення просвітницько-інформаційної діяльності, як ознаки успішної соціальної реклами (вплив побаченої реклами на людину - чи помітять, чи задумаються, чи звернуть увагу на проблему). Також важливим є правильність викладу самого меседжу. В ньому не має бути залякувань чи перебільшень. Головним завданням соціальної реклами $\epsilon$ донесення правильних пріоритетів в житті та, що саме це найкращий вибір для здорової людини (наприклад відсутність шкідливих звичок, вибір на користь здорового способу життя );

3) сприяння участі соціальних установ та їх послуг. Адже, коли виникає складна ситуація, людина не знає куди звернутися, а через почуття сорому не може попросити допомоги у близьких. Правильно вказана інформація (телефон, адреса, перелік послуг, чи анонімна форма); рекламування тренінгів, семінарів, консультацій, які проводяться різними центрами;

4) соціально-виховний аспект, що включає: планування рекламної кампанії в залежності від прогнозування зміни в свідомості аудиторії; переосмислення значень суспільно бажаних цінностей; аналізування всіх минулих проблем та проблем сьогодення; усвідомлення особистісної значимості проблем та зміна емоційного ставлення; зміна та/або відмова від неприйнятних точок зору суспільної моралі моделей поведінки (Осетрова (ред.), 2016).

Коректною рекламою називають рекламу, яка може викликати в людині емоції, що скорегують емоції щодо проблеми або складної ситуації, здатна змусити замислитись про проблему, допоможе знайти вихід або сприятиме появі бажання допомогти іншій людині. Зважаючи на це, більшість реклами в Україні не можна назвати коректною. Головною причиною $є$ те, що ініціаторами в більшості є комерційні організації. Пояснюється це тим, що задля створення реклами потрібні фінансові ресурси і в результаті некомерційна реклама стає комерційною. Якщо ж говорити про рекламу державних соціальних установ, то їхня реклама в більшості внутрішня. Тобто розповсюджується між тими, хто вже прийшов до них. Тому необхідно підвищувати рівень розвитку соціальної реклами за межі соціальних служб, зробити ії соціальною по справжньому. 
Соціальна реклама є можливістю змінити ідеї та життєві принципи, відіграти роль засобу соціалізації та превенції, проінформувати та попередити, провести профілактичні заходи та вплинути на те, на що не можуть інші види комунікації на безкоштовних та масових засадах. Тому поширювати некомерційну рекламу повинні не тільки маркетологи, а міждисциплінарні команди фахівців - у співпраці з соціальними працівниками та соціологами.

Як частина соціальної роботи, соціальна реклама дозволяє:

- інформувати суспільство на тему важливих програм соціального обслуговування, потреб та проблем, корисних соціальних проблем;

- розповідати про соціальне забезпечення, яке може допомогти різним кризовим ситуаціям в житті людей;

- пояснювати людям як діяти в складних ситуаціях, допомагати безробітним, батькам-одинакам;

- надавати корисну інформацію вразливим групам населення (люди 3 інвалідністю, психічно хворі, люди похилого віку);

- консультувати людей, близькі люди яких потрапили в СЖО;

- допомагати в створенні груп самодопомоги, взаємодопомоги, поширення серед громадськості.

Таким чином, некомерційна реклама має відігравати ключову роль у практичній соціальній роботі як один з інструментів сприяння позитивним змінам i розвитку в суспільстві, громадах, житті груп і окремих людей. При цьому повинні реалізовуватися всі іï основні функції, зокрема інформаційна, координаційна, перескерування, профілактична, педагогічного впливу тощо (Осетрова (Ред.), 2016).

\section{Висновки}

Проведене дослідження дає підстави зробити такі висновки. Соціальна реклама $\epsilon$ законодавчо визначеною формою надання соціальної послуги профілактики, що використовується в сучасній практиці соціальної роботи 3 метою запобігання СЖО і урахуванням потреб певної цільової групи чи громади, суспільства загалом. Соціальна реклама як сучасна практика соціальної роботи виконує інформаційну, просвітницьку, консультаційну, виховну, координаційну, профілактичну функції.

Водночас соціальна реклама не $є$ сугестією або ж прямою пропагандою. Це розмова між людиною, проблемою та соціумом; допомога людині у вирішенні складних ситуацій і набутті здатності по-новому подивитися на СЖО і власні ресурси у їх подоланні. У такий спосіб соціальна реклама виконує завдання соціальної роботи - сприяння позитивним змінам в житті людей. Така реклама може мати прямий реальний вплив на суспільство та життєві цінності, працювати на випередження складних ситуацій та допомагати не тільки людині, яка 
потребує допомоги, а й соціальному працівнику у вирішенні поставлених завдань. Для цього необхідні умови на державному рівні: збільшення кількості зовнішньої соціальної реклами від Міністерства соціальної політики України, некомерційних організацій, закладів, що надають соціальні послуги; розмежування соціальної реклами від політичної, комерційної реклами та інших видів реклами; дотриманя вимог етики і відповідальності замовників, виконавців, розповсюджувачів соціальної реклами.

\section{Література}

Boddy, J. \& Dominelli, L. (2016). Social Media and Social Work: The Challenges of a New Ethical Space. Australian Social Work, №10, C. 172-184 https://doi.org/10.1080/0312407 X.2016.1224907

Glanz, K., Rimer, B. K., \& Viswanath, K. (2008). Theory, research, and practice in health education. In K. Glanz, B. K. Rimer, \& K. Viswanath (Eds.), Health behavior and health education: Theory research and practice (pp. 21-40). San Francisco, CA: Jossey-Bass.

Брижовата, O., Волгіна, О. (2003). Роль соціального працівника у представництві інтересів вразливих верств населення та зокрема осіб, які мають алкогольну та наркотичну залежність. Соиіально-психологічна реабілітаџія людей із залежністю від наркотичних речовин. Київ: Граффітті Груп, С. 69-75.

Вайнола, Р. Х., Лях, Т. Л. (Ред.) (2007). Активні методи просвітнииької діяльності у профілактиці ВІЛ/СНІДу та ризикованої поведінки : посіб. для спец. приймальників-розподільників, притулків для неповнолітніх та виховних колоній. К.: ТОВ „ДКБ „РОТЕКС”, 190 с.

Дані звіту Національної ради «Соціальна реклама на телебаченні»(2019). URL: https://www.nrada.gov.ua/ua-pershyj-lidyruye-sered-telekanaliv-za-pokazomsotsialnoyi-reklamy/

Журавель, Т. В. (2013). Соціальна профілактика як напрям соціальнопедагогічної діяльності. В О.В. Безпалько (Ред.) Соиіальна педагогіка: навч. посібник К.: Академвидав, 312 с.; С. 85-101.

Золотова, Г. Д. (2004). Нові підходи до профілактики адиктивної поведінки. Соиіальна педагогіка: теорія та практика, №1, С. 74-79.

Капська, А. Й. (Ред.) (2009). Профілактика негативних явищ у молодіжному середовищі. Соціальна педагогіка. Київ, С. 357-360.

Лаврик, О. В. (2008). Соціальна реклама в сучасному медіапросторі: до визначення поняття. Филология. Социальная коммуникация, №1., С. 65-70.

Линник, Л. М. (2006). Соціально-педагогічні засади профілактичної роботи $з$ важковиховуваними підлітками. Луцьк.

Лютий, В. П. (2008). Соціальна профілактика. Соціальна педагогіка: мала енциклопедія. К.: Центр учбової літератури, 207 с. 
Обритько, Б. А. (2002). Рекламна діяльність: курс лекцій. МАУП, 240 с.

Оржеховська, В. М. (Ред.) (2008). Словник основних термінів $i$ понять превентивного виховання.Т.: ТзОВ “Терно-граф”, 200 с.

Осетрова, О. О. (Рред.) (2016). Соціальна робота в Україні: основні напрями, проблеми та перспективи розвитку. Матеріали Всеукраїнської науковопрактичної конференції. Д.: ДНУ., 147 с.

Пархоменко, С. А. (2011). Соиіальна реклама як культурний феномен. URL: http://www.nbuv.gov.ua/portal/soc_gum.

Пихтіна, Н. П. (2007). Профілактика та соціально-педагогічна робота $з$ дітьми девіантної поведінки: навчально-методичний посібник. Ніжин: Видавництво НДУ ім. М. Гоголя, 239 с.

Піча, В., Гайдук, Н., Клос, Л. (Укл.), В. Піча (Ред.) (2014). Все про соиіальну роботу. Львів: Новий Світ-2000.

Практика. (1976). Словник украӥнської мови: в 11 mомах, 7, 513 с. URL: http://sum.in.ua/s/praktyka

Романовська, Л. (2019). Соціальна реклама у профілактиці девіантної поведінки молоді. Social Work and Education, 6(1), 52-61.

Семигіна, Т. (2020). Сучасна соціальна робота. Київ: Академія праці, соціальних відносин і туризму.

Скрипка, I. В., Семигіна, Т. В. (2014). Практика колективного представництва інтересів в Україні (на прикладі людей, які живуть з ВІЛ/СНІДом). Наукові записки НаУКМА, №162, С. 62-67.

Табачковський, В. (2002). Практика. Філософський енциклопедичний словник, за ред. В.І.Шинкарук (гол.редколегії). Київ: Абрис.

Україна, Міністерство соціальної політики (2015). Наказ «Про затвердження Державного стандарту соціальної послуги профілактики», № 912. URL: https://zakon.rada.gov.ua/laws/show/z1155-15\#Text.

Яненко, Я. В. (2017). Соціальна реклама як чинник соціалізації у сучасному суспільстві. URL: http://obraz.sumdu.edu.ua/wp-content/uploads/2018/02/18.pdf.

Яременко, О. О. (2005). Тютюн, алкоголь, наркотики в молодіжному середовищі: вживання, залежність, ефективна профілактика, 7. Київ: Держ ін-т пробл. сім. та мол., Укр. ін-т соц. д-нь. 196 с. 


\section{SOCIAL ADVERTISING AS A TOOL FOR SOCIAL WORK IN UKRAINE}

Liliia Klos, Doctor of Sciences (Pedagogy), docent, Head of the Department of Sociology and Social Work, Lviv Politechnic University, Lviv, Ukraine; liliia.y.klos@lpnu.ua

Oleksandra-Mariia Dzhavadian, Master of Social Work, 2nd year student of the Doctor of Philosophy training program in the specialty "Social Work", Lviv Politechnic University, Lviv, Ukraine; alexandradzhavadian@gmail.com

Abstract. The article considers some aspects of social advertising in Ukraine, describes the main characteristics of social advertising as one of the modern practices in Ukraine, as well as prospects for the development and application of social advertising in professional social work. The types of social advertising, the functions it performs in the system of social work and the tasks it can perform in the future are determined. Theoretical works of domestic and foreign experts, as well as reports on social advertising, reports of the National Council are analyzed. They allow us to conclude that a social worker, through social advertising, can prevent, promote socialization, adaptation, information and improve the social climate in the country, warn society about certain problems and minimize their spread.

The study gives grounds to draw the following conclusions that social advertising is a legally defined form of providing a social prevention service used in modern practice of social work in order to prevent CLC. At the same time, social advertising is not direct propaganda. It is a conversation between a person, a problem and a society; helping a person to solve difficult situations and gaining the ability to look at their own resources in a new way. Such advertising can have a direct real impact on society and life values, work to anticipate difficult situations and help not only the person but also the social worker in solving the tasks. This requires conditions at the state level: increasing the number of outdoor social advertising from the Ministry of Social Policy of Ukraine, non-profit organizations, institutions providing social services; differentiation of social advertising from political, commercial advertising and other types of advertising; compliance with the requirements of ethics and responsibility of customers, performers, distributors of social advertising.

Keywords: social advertising; prevention; social work practice; social prevention service. 


\section{References}

Boddy, J. \& Dominelli, L. (2016). Social Media and Social Work: The Challenges of a New Ethical Space. Australian Social Work, 10, p. 172-184. https://doi.org/10.1080/0312407X.2016.1224907

Glanz, K., Rimer, B. K., \& Viswanath, K. (2008). Theory, research, and practice in health education. In K. Glanz, B. K. Rimer, \& K. Viswanath (Eds.), Health behavior and health education: Theory research and practice (pp. 21-40). San Francisco, CA: Jossey-Bass.

Brizhovata, O., Volgina, O. (2003). The role of the social worker in representing the interests of vulnerable groups and in particular people with alcohol and drug addiction. Socio-psychological rehabilitation of people with drug addiction. Kyiv: Graffiti Group, 69-75 [in Ukrainian].

Vainola, R. H., Lech, T. L. (Eds.). (2007). Active methods of educational activities in the prevention of HIV / AIDS and risky behavior: a guide. for special receiversdistributors, shelters for minors and educational colonies. K.: LLC «DKB» «ROTEX», 190 p. [in Ukrainian].

Data from the report of the National Council «Social Advertising on Television» (2019). URL: https://www.nrada.gov.ua/ua-pershyj-lidyruye-sered-telekanaliv-zapokazom-sotsialnoyi-reklamy/ [in Ukrainian].

Zhuravel, T. V. (2013). Social prevention as a direction of socio-pedagogical activity. In OV Bezpalko (Ed.) Social pedagogy: textbook. manual K.: Akademvydav, 312 p.; 85-101 [in Ukrainian].

Zolotova, H. D. (2004). New approaches to the prevention of addictive behavior. Social pedagogy: theory and practice, 1, 74-79 [in Ukrainian].

Kapska, A. Y. (Ed.) (2009). Prevention of negative phenomena in the youth environment. Social pedagogy. Kyiv, 357-360 [in Ukrainian].

Lavrik, O. V. (2008). Social advertising in the modern media space: to define the concept. Philology. Social Communication, №1., 65-70 [in Ukrainian].

Linnik, L. M. (2006). Socio-pedagogical principles of preventive work with difficult adolescents. Lutsk [in Ukrainian].

Lyutyj, V. P. (2008). Social prevention. Social pedagogy: a small encyclopedia. K .: Center for Educational Literature, 207 [in Ukrainian].

Obritko, B. A. (2002). Advertising: a course of lectures. MAUP, 240 p.

Orzhekhovska, V. M. (Ed.) (2008). Dictionary of basic terms and concepts of preventive education. T .: LLC «Terno-graf», $200 \mathrm{p}$. [in Ukrainian].

Osetrova, O. O. (ed.) (2016). Social work in Ukraine: main directions, problems and prospects of development. Proceedings of the All-Ukrainian scientific-practical conference. D.: DNU, 147 p. [in Ukrainian].

Parkhomenko, S. A. (2011). Social advertising as a cultural phenomenon. URL: http://www.nbuv.gov.ua/portal/soc_gum [in Ukrainian]. 
Pikhtina, N. P. (2007). Prevention and socio-pedagogical work with children of deviant behavior: a textbook. Nizhyn: NDU Publishing House. M. Gogol, 239 p. [in Ukrainian].

Picha, V. \& Gaiduk, N. \& Klos, L. (Inc.), V. M. Picha (Ed.) (2014). All about social work. Lviv: New World - 2000 [in Ukrainian].

Practice (1976). Dictionary of the Ukrainian language: in 11 volumes, 7, 513. http://sum.in.ua/s/praktyka [in Ukrainian].

Romanovska, L. (2019). Social advertising in the prevention of the questionality of youth. Social Work and Education, 6(1), 52-61.

Semigina, T. (2020). Modern social work. Kyiv: Academy of Labor, Social Relations and Tourism [in Ukrainian].

Violin, I. V., Semigina, T. V. (2014). The practice of collective representation of interests in Ukraine (on the example of people living with HIV/AIDS). Scientific Notes of NaUKMA, 162, 62-67 [in Ukrainian].

Tabachkovsky, V. (2002). Practice. Philosophical Encyclopedic Dictionary, ed. VI Shinkaruk (chief editorial board). Kyiv: Abris [in Ukrainian].

Ukraine, Ministry of Social Policy (2015). Order «On approval of the State standard of social prevention services» № $912 \mathrm{https} / /$ zakon.rada.gov.ua/laws/show/z115515\#Text [in Ukrainian].

Yanenko, Ya. V. (2017). Social advertising as a factor of socialization in modern society. URL: http://obraz.sumdu.edu.ua/wp-content/uploads/2018/02/18.pdf [in Ukrainian].

Yaremenko, O. O. (2005). Tobacco, alcohol, drugs in the youth environment: use, dependence, effective prevention, 7. Kyiv: State Institute of Probl. seven. and mol., Ukr. Inst. of Soc. Mr. 196 p. [in Ukrainian].

\section{Article history:}

Received: April 09, 2021

1st Revision: April 28, 2021

Accepted: May 30, 2021 